\title{
SYSTEMIC PHLEBOTROPIC DRUGS IN PHARMACOTHERAPY OF CHRONIC VENOUS INSUFFICIENCY OF THE LOWER EXTREMITIES
}

\author{
D.V.Okley \\ National University of Pharmacy \\ Key words: chronic venous insufficiency; phlebotropic drugs; micronized purified flavonoid fraction
}

\begin{abstract}
The modern aspects of pharmacotherapy of chronic venous insufficiency (CVI) of the lower extremities are presented in the article. Phlebotropic drugs are medications for basic pharmacotherapy of CVI. A common characteristic of pharmacodynamics of these drugs is the ability to increase the venous tone, and reduce severity of specific symptoms and syndromes of CVI. The efficiency of the most widespread venotonic drugs has been analyzed. The largest number of preclinical and clinical research among all groups of veno-active drugs has been devoted to the study of Micronized Purified Flavonoid Fraction (MPFF). It has been determined that the therapeutic effect of MPFF is higher compared to the therapeutic effect of non-micronised Diosmin. An important feature of the action of MPFF is a rapid onset of the venotonic effect, the effect is shown already from the first hour after administration and lasts during the day. This action is successfully complemented by improved rheological properties of the blood, reduction in blood viscosity, stimulation of the drainage function of lymphatic vessels. Treatment should be given by courses, which duration depends on disease severity, and is for 2-3 months, but not less than twice a year. The continuous therapeutic scheme can be used in the case of refractory forms of CVI. MPFF is characterized by a high clinical efficacy, high bioavailability and safety. It does not cause serious adverse reactions, well tolerated and can be used as a drug of the first choice.
\end{abstract}

Chronic venous insufficiency (CVI) of the lower extremities is a syndrome characterized by disorders of the venous outflow on the macrohemodynamic level, it leads to disorganization of the regional microcirculation system $[6,16]$. CVI is considered to be the most common peripheral vascular disease. The high level of morbidity of the working-age population reaching $40-50 \%$ by expert estimations allows to conclude that CVI is an important medical and social problem. Furthermore, if previously the disease was predominantly a problem of persons of the senior age group (over 50 years), at the present time the first signs of venous reflux are found in $10-15 \%$ of $12-13$ years school children [5, 24].

The main predisposing factors of CVI are:

- hereditary or acquired valvular insufficiency of the veins;

- decrease of the tone of the varicose vein wall;

- high pressure due to the blood reflux from the deep venous system to the surface venous system [7,21, 22].

CVI of the lower extremities is primarily characterized by stagnation or redistribution of the venous blood flow in the venous system. The mechanism of its development is associated with hypertension in the inferior vena cava forming as a result of the varicose transformation of the venous wall or its thrombus burden $[6,22]$. Initial macrohemodynamic disorders lead to the serious changes at the tissue level. The result of this process is development of microcirculatory disorders in the form of trophic disorders.

Until recently, the sufficient attention has not been paid to pharmacotherapy of CVI in Ukraine. The cause for this situation is the absence of effective, available and safe drugs. The situation has radically changed in the last two decades when the improvement of pharmaceutical technologies has led to the appearance a new generation of phlebotropic drugs at the pharmaceutical market $[4,5,7]$.

Medications of the basic pharmacotherapy CVI are phlebotropic drugs (PHD) (synonyms are veno-active drugs, phleboprotector drugs, venotonic drugs). They are a heterogeneous group of biologically active substances obtained by processing of plant raw material or by chemical synthesis. The ability to increase the venous tone and reduce the venospecific symptoms and syndromes of CVI is a common feature of the pharmacodynamics of these drugs $[1,18]$.

It should be noted that more than 20 PHD have been registered and are used in Ukraine. The main phlebotropic drugs and their daily doses are shown in Table 1.

Flavonoids are the most studied among the basic venotonic drugs. Drugs based on Diosmin, which are especially widely used in the international phlebological practice, are prescribed more often than others [1, 2, 13]. Most experts call Micronized Purified Flavonoid Fraction (MPFF), which has the brand name "Detralex", the reference phleboprotector drug because of its multitargeted mechanism of action, ease of use, high bioavailability and safety $[3,12,20]$.

An important feature of micronized Diosmin is a rapid onset of the venotonic effect, the effect is shown already from the first hour after administration, and lasts during the day $[1,15]$. This action is successfully 
Table 1

Basic phlebotropic drugs

\begin{tabular}{|c|c|c|c|}
\hline Trade name of the drug & Chemical group & Active component & Daily dose, $\mathrm{mg}$ \\
\hline Herbion aesculus & $\alpha$-Benzopyrones & Coumarin & $100-400$ \\
\hline Anavenol, Venoruton & \multirow{3}{*}{ Flavonoids } & Hydroxyethyl rutoside & $1000-3500$ \\
\hline Venorutinol, Troxevasin & & Troxerutin & $1000-3500$ \\
\hline Detralex, Phlebodia & & Diosmin & $600-1000$ \\
\hline Endotelon & $\begin{array}{c}\text { Pycnogenols } \\
\text { (Proanthocyanidins) }\end{array}$ & $\begin{array}{l}\text { Procyanidolic oligomers } \\
\text { (grape seed extract) }\end{array}$ & 300 \\
\hline Aescusan, L-Lysine Aescinat & \multirow{2}{*}{ Saponins } & Escin (horse chestnut extract) & $60-120$ \\
\hline Gotu Cola & & Centella asiatica ("clever herb") & $400-800$ \\
\hline Ginkor Fort, Tanakan & \multirow{2}{*}{ Saponins and flavonoids } & Ginkgo biloba & $60-120$ \\
\hline Cyclo 3 Fort & & Ruscus aculeatus & $300-450$ \\
\hline Tonopress & \multirow{2}{*}{ Ergot alkaloids } & Dihydroergotamine & $2.5-7.5$ \\
\hline Redergin & & Dihydroergocristine & $2.5-7.5$ \\
\hline Glyvenol & \multirow{2}{*}{ Synthetic compounds } & Tribenoside & 800 \\
\hline Doxi-Chem & & Calcium dobesilate & $1000-1500$ \\
\hline
\end{tabular}

complemented by improved rheological properties of the blood, reduction in blood viscosity [2,3], stimulation of the drainage function of lymphatic vessels $[11,23]$.

Most PHD increase the tone of peripheral veins and lymphatic vessels due to the effect on the norepinephrine-dependent mechanism, and also due to some specific effects of individual drugs [8]. Requirements for PHD are not limited only by increase of the venous wall tone. Modern veno-active drugs should have the ability to stimulate the lymphatic drainage and improve microcirculation $[9,15]$. Basic clinical effects of different PHD are presented in Table 2.

The main indication for the use of PHD is the symptoms associated with chronic venous insufficiency such as heavy legs, discomfort, itching, pain along the varicose veins, paresthesia, night cramps, and other venospecific complaints, chronic venous edema, and trophic skin disorders, including venous ulcers. The results of numerous clinical studies suggest that at early stages of the disease all PHD have a good therapeutic effect on subjective symptoms of CVI, but not the objective symptoms of CVI such as telangiectasia, varicose reticular and subcutaneous veins $[10,13]$. At the same time in choosing the drug therapy at early stages of CVI the preference should be given to PHD with the efficacy and safety proven in randomized controlled clinical studies. Chronic venous edema is an absolute indication for PHD [14]. According to the meta-analysis data MPFF shows the most evident anti-edematous effect, which is the drug of first choice in chronic venous edma [15].

Hydroxyethyl rutosides (Venoruton) and the extract of Ruscus aculeatus (Cyclo 3 fort) also reduce the chronic venous edema and can be the second line drugs. Efficiency of non-micronized (native) Diosmin in regard to the chronic venous edema is not significantly different from placebo. To assess the efficiency of other phlebotropic drugs in the chronic venous edema it is necessary to conduct numerous randomized clinical studies according to standardized protocols $[11,29]$.
Phlebotropic drugs should be administered in adequate doses, which are recommended by drug manufacturers, as well as the standard therapeutic schemes and duration of treatment should be observed. The excess of the standard daily doses does not necessarily improve the clinical effect, but increases the frequency of unwanted side effects that can break the started course of pharmacotherapy. However, results of certain clinical research indicate that in some clinical situations

Table 2

The therapeutic effects and mechanisms of action of phlebotropic drugs

\begin{tabular}{|l|l|}
\hline \multicolumn{1}{|c|}{$\begin{array}{c}\text { Therapeutic effects and } \\
\text { mechanisms of action }\end{array}$} & \multicolumn{1}{|c|}{ PHD } \\
\hline $\begin{array}{l}\text { Antiedematous and capillary } \\
\text { protective }\end{array}$ & All phlebotropic drugs \\
\hline Analgesic (venous pain) & MPFF, grape seed extract \\
\hline Venotonic & All phlebotropic drugs \\
\hline Lymphotropic & $\begin{array}{l}\text { MPFF, Ruscus aculeatus } \\
\text { extract }\end{array}$ \\
\hline Rheological & MPFF, Troxerutin, Rutin \\
\hline Profibrinolytic & MPFF, Troxerutin, Diosmin \\
\hline Anti-inflammatory & $\begin{array}{l}\text { MPFF, Diosmin, Ginkgo } \\
\text { biloba extract }\end{array}$ \\
\hline $\begin{array}{l}\text { Inhibition of leukocyte- } \\
\text { endothelial adhesion }\end{array}$ & MPFF \\
\hline $\begin{array}{l}\text { Protection of the venous } \\
\text { valves }\end{array}$ & MPFF \\
\hline $\begin{array}{l}\text { Protection of the venous wall: } \\
\text { - inhibition of lysosomal } \\
\text { enzymes } \\
\text { stabilization of collagen } \\
\text { - suppression of free radicals } \\
\text { normalization of PGE2 } \\
\text { synthesis } \\
\text { improvement of circulation } \\
\text { in the vasa vasorum }\end{array}$ & • MPFF, oligomers \\
\hline
\end{tabular}


Table 3

The possible unwanted side effects when using different phlebotropic drugs

\begin{tabular}{|l|c|c|l|}
\hline \multicolumn{1}{|c|}{ Active component } & $\begin{array}{c}\text { Skin } \\
\text { reactions }\end{array}$ & $\begin{array}{c}\text { Dyspeptic } \\
\text { reactions }\end{array}$ & \multicolumn{1}{|c|}{ Other adverse drug reactions } \\
\hline Oxerutin and rutosides & Often & Often & \\
\hline Escin (horse chestnut extract) & + & + & Dizziness, headache, rash \\
\hline Ruscus aculeatus extract & & + & \\
\hline Grape seed extract & + & Often & Dizziness, headache, rash, tachycardia \\
\hline Ginkgo biloba extract & + & + & \\
\hline Troxerutin & Often & + & Dizziness, tachycardia, weakness \\
\hline Diosmin & & + & $\begin{array}{l}\text { Rare vegetative reactions such as } \\
\text { dizziness and weakness }\end{array}$ \\
\hline MPFF & & + & Agranulocytosis \\
\hline Calcium dobesilate & + & + &
\end{tabular}

the increase in the dose of the phlebotropic drug can increase its therapeutic efficacy. In this connection, in situations when the benefit of the drug outweighs the potential risk, the dose of the phlebotropic drug can be increased after documentary evidence and obtaining of the informed consent of the patient [17].

Phlebotropic drugs can be prescribed as monotherapy or fixed combinations (multi-drug) since the simultaneous use of two or more drugs belonging to related chemical classes does not intensify the therapeutic effect, but increases the probability of undesirable side reactions.

PHD are relatively well tolerated by most patients even if taken them for long time. The undesirable dyspeptic disorders (stomach pain, diarrhea, vomiting, etc.) and vegetative disorders (insomnia, dizziness, etc.) are observed in no more than 5\% of patients [23]. The typical undesirable side reactions of various PHD are presented in Table 3.

Treatment should be given by courses, which duration depends on disease severity, and lasts 2-3 months, but not less than twice a year. The interval between courses should be used for physical therapy or SPA treatment. The continuous therapeutic scheme can be used in the case of refractory forms of CVI [7, 25]. MPFF has the highest safety profile in the long-term use (6-12 months) [1, 3, 19, 20].
According to standard protocols adapted to each stage and form of CVI the randomized controlled clinical studies should be conducted for all new phlebotropic and phleboprotector drugs in order to assess their efficacy and safety $[16,25]$. Formal bioequivalence of generic and original drugs can not guarantee the similar clinical effect and safety $[1,7,20]$.

\section{CONCLUSIONS}

In conclusion, it should be noted that the rational pharmacological therapy allows to perform effective pathogenetic and symptomatic treatment of various forms and complications of CVI. The promising development of this method is implemented in several directions. Among them the following ones should be distinguished:

- the search of new chemical substances which selectively block the synthesis of adhesion molecules, leukocyte activation factors and tissue metalloproteases;

- the study of drugs that stimulate and control the synthesis of the connective tissue;

- optimization of delivery methods of pharmacological agents in the affected area with the help of nanotechnology.

The successful implementation of these programmes in the future will allow to speak about the possibility of the effective control of CVI.

\section{REFERENCES}

1. Богачев В.Ю., Голованова О.В., Кузнецов А.Н. и др. // Ангиол. и сосудистая хирургия. - 2013. - Т. 19, №1. - C. 73-81.

2. Засорин А.А., Макарова Н.П., Нарицина В.В. // Флебол. - 2011. - №1. - С. 22-24.

3. Кириенко А.И., Богачев В.Ю., Золотухин И.А. и др. // Соnsilium medicum. Хирургия. - 2007. - №1. C. 45-49.

4. Литвиненко О.О., Коноваленко В.Ф., Бугайиов С.Г. и др. // Укр. тер. журн. - 2013. - №2. - С. 116-123.

5. Олійник М.В., Приходько В.Ю. // Ліки Украӥни. - 2010. - №3 (12). - С. 24-29.

6. Савельев В.С., Гологорский В.А., Кириенко А.И. и др. - М.: Медицина, 2001. - 664 с.

7. Усенко О.Ю., Нікульніков П.І., Чернуха Л.М. та ін. Клініко-практ. рекоменд. - К., 2014. - 120 с.

8. Янушко В.А., Небылицин Ю.С., Климчук И.П. // Новости медициныл. - 2013. - №6. - С. 70-73.

9. Agus G.B. // Phlebolymphol. - 2013. - Vol. 20 (2). - P. 101-111.

10. Allaert F.A. // Int. Angiol. - 2012. - Vol. 31 (4). - P. 310-315. 
11. Belczak S.Q., Sincos I.R., Campos W. et al. // Phlebol. - 2014. - Vol. 29 (7). - P. 454-460.

12. Burak F., Gunduz T., Simsek M. et al. // Phlebolymphol. - 2009. - Vol. 16(3). - P. 290-294.

13. Cazaubon M., Bailly C., Ducros E. S. et al. // Angiol. - 2011. - Vol. 63(2). - P. 2-48.

14. Cohen J.M., Akl E.A., Kahn S.R. // Chest. - 2012. - Vol. 141 (2). - P. 308-320.

15. Fotiadis E., Kenanidis E., Samoladas E. et al. // Arch. Orthop. Trauma Surg. - 2011. - Vol. 131 (3). - P. 389-392.

16. Gillet J.L. // Medicographia. - 2011. - Vol. 33. - P. 285-291.

17. Gloviczki P., Comerota A.J., Dalsing M.C. et al. // J. Vasc. Surg. - 2011. - Vol. 53 (Suppl. 5). - P. 2S-48S.

18. Marinovic K.S., Lupi D. // Acta Dermatovenerol. Croat. - 2012. - Vol. 20 (3). - P. 197-200.

19. Mowatt-Larssen E., Shortell C. // Vasc. Surg. - 2012. - Vol. 23. - P. 118-122.

20. Nicolaides A. // Phlebolymphol. - 2009. - Vol. 16 (4). - P. 340-346.

21. Pannier F., Rabe E. // Phlebol. - 2012. - Vol. 27. - P. 23-26.

22. Pereira A.J. // Rev. Port. Cir. Cardiotorac. Vasc. - 2010. - Vol. 15 (1). - P. 51-56.

23. Perrin M., Ramelet A.A. // Eur. J. Vasc. Endovasc. Surg. - 2011. - Vol. 41 (1). - P. 117-125.

24. Rabe E., Guex J.J., Puskas A. et al. // Int. Angiol. - 2012. - Vol. 31 (2). - P. 105-115.

25. Word R. // Surg. Clin. N. Am. - 2010. - Vol. 90. - P. 1195-1214.

\section{СИСТЕМНІ ФЛЕБОТРОПНІ ПРЕПАРАТИ У ФАРМАКОТЕРАПІЇ ХРОНІЧНОЇ ВЕНОЗНОЇ НЕДОСТАТНОСТІ НИЖНІХ КІНЦІВОК \\ Д.В.Оклей}

Ключові слова: хронічна венозна недостатність; фрлеботропні препарати; мікронізована очищена фрракція фрлавоноїдів

Наведені сучасні аспекти фрармакотерапії хронічної венозної недостатності (XBH) нижніх кінцівок. Засобами базисної фармакотерапії ХВН служать фрлеботропні лікарські препарати. Загальна особливість їх фрармакодинаміки - здатність підвищувати венозний тонус, а також зменшувати вираженість веноспецифрічних симптомів і синдромів. Проаналізовано ефрективність найбільш поширених венотонічних препаратів. Серед усіх груп веноактивних препаратів найбільша кількість досліджень стосується вивчення мікронізованої очищеної фрракції фрлавоноїдів (МОФФ). Встановлено, що терапевтичний ефект МОФФ вище в порівнянні з немікронізованим діосміном. Важлива особливість дії МОФФ - швидкий, вже з першої години після прийому початок венотонічного ефекту, який зберігається протягом доби. Ця дія вдало доповнюється поліпшенням реологічних властивостей крові, зниженням її в'язкості, стимуляцією дренажної фрункції лімфратичних судин. Лікування слід проводити курсами, тривалість яких залежить від тяжкості захворювання і складає 2-3 міс., не рідше двох разів на рік. У разі рефррактерних фрорм ХВН може бути використана безперервна схема фрармакотерапії. МОФФ характеризується високою клінічною ефрективністю, має високу біодоступність та безпеку, не викликає серйозних побічних реакцій, добре переноситься хворими і може застосовуватися як препарат першого вибору.

\section{СИСТЕМНЫЕ ФЛЕБОТРОПНЫЕ ПРЕПАРАТЫ В ФАРМАКОТЕРАПИИ ХРОНИЧЕСКОЙ ВЕНОЗНОЙ НЕДОСТАТОЧНОСТИ НИЖНИХ КОНЕЧНОСТЕЙ Д.В.Оклей}

Ключевые слова: хроническая венозная недостаточность; фрлеботропные препараты; микронизированная очищенная фрракция фрлавоноидов

Приведены современные аспекты фрармакотерапии хронической венозной недостаточности (ХВН) нижних конечностей. Средствами базисной фрармакотерапии ХВН служат фрлеботропные лекарственные препараты. Общая особенность их фрармакодинамики - способность повышать венозный тонус, а также уменьшать выраженность веноспецифичных симптомов и синдромов. Проанализирована эфффективность наиболее распространенных венотонических препаратов. Среди всех групп веноактивных препаратов наибольшее количество исследований касается изучения микронизированной очищенной фрракции фрлавоноидов (МОФФ). Установлено, что терапевтический эфрфрект МОФФ выше по сравнению с немикронизированным диосмином. Важная особенность действия МОФФ - быстрое, уже с первого часа после приема начало венотонизирующего эфрфекта, сохраняющегося в течение суток. Это действие удачно дополняется улучшением реологических свойств крови, снижением её вязкости, стимуляцией дренажной ффункции лимфратических сосудов. Лечение следует проводить курсами, продолжительность которых зависит от тяжести заболевания и составляет 2-3 мес., не реже двух раз в год. В случае рефрактерных фрорм ХВН может быть использована непрерывная схема фрармакотерапии. МОФФ характеризуется высокой клинической эфффективностью, имеет высокую биодоступность и безопасность, не вызывает серьезных побочных реакций, хорошо переносится больными и может применяться как препарат первого выбора. 